\title{
INVESTIGATION OF THE RAW MATERIALS FROM THE PRECISION CASTING PROCESS FOR VIABILITY EVALUATION OF RECYCLING THE GENERATED CERAMIC SHELL WASTE
}

INVESTIGAÇÃO DAS MATÉRIAS PRIMAS DO PROCESSO DE FUNDIÇÃO DE PRECISÃO PARA AVALIAÇÃO DA VIABILIDADE DA RECICLAGEM DO RESÍDUO CASCA CERÂMICA GERADO

\author{
ALINI LUÍSA DIEHL CAMACHO, M.SC. | UNISINOS \\ REGINA CÉLIA ESPINOSA MODOLO, Dra.| UNISINOS \\ VICTOR MIGUEL FERREIRA, Dr.| UA-PT - Portugal \\ FERNANDO JOAQUIM FERNANDES TAVARES ROCHA, Dr. | UA-PT - Portugal \\ CARLOS ALBERTO MENDES MORAES, Dr. | UNISINOS
}

\begin{abstract}
The goal of this study is to evaluate the recycling potential of the solid waste generated in the precision casting industrial process. The methodology consisted in the physical, chemical, mineralogical, and thermal (DTA) characterization of the raw materials used in the industrial process, as well as of the generated solid waste, called ceramic shell waste (CSW). The results obtained demonstrated that the silica raw material suffers a transformation of phases. Analyzing the waste, it was verified that it is constituted by the crystalline silica phase of quartz and, in this way, it must be benefited in order to separate the noble materials present, such as chamottes and zirconium components. Furthermore, the fraction of crystalline silica, which, if reused, may give fragility to the recycled ceramic shell due to abrupt volume changes characterized by the silica polymorphs, must be removed.
\end{abstract}

KEY WORDS: Ceramic shell waste; Precision casting; Materials characterization; Recycling.

\section{RESUMO}

O objetivo deste estudo é avaliar o potencial de reciclabilidade do resíduo gerado no processo industrial de fundição de precisão. Na metodologia utilizada fez-se a caracterização física, química, mineralógica e térmica (DTA) das matérias primas utilizadas no processo industrial, bem como do resíduo gerado, denominado resíduo de casca cerâmica $(R C C)$. Os resultados obtidos demonstraram que as matérias primas sílicas sofrem transformação de fases. Analisando o resíduo, verificou-se que ele constitui a fase sílica cristalina de quartzo e desta forma, ele deve ser beneficiado de forma a separar os materiais nobres presentes como chamotes e componentes de zircônio. Ainda, deve-se remover a fração de silica cristalina que, se reutilizada, pode conferir fragilidade à casca cerâmica reciclada em função de mudanças abruptas de volume caracterizadas pelos polimorfos da sílica.

PALAVRAS-CHAVE: Resíduo casca cerâmica; Fundição de precisão; Caracterização de materiais; Reciclagem. 


\section{INTRODUCTION}

Refractory ceramic raw materials have been used, in the precision casting industry, to produce the ceramic mold using basically zirconite $\left(\mathrm{ZrSiO}_{4}\right)$, around $98 \%$ on a dry basis, aluminosilicates $\left(3 \mathrm{Al}_{2} \mathrm{O}_{3} \cdot 2 \mathrm{SiO}_{2}\right)$, named chamottes, which are used in different granulometries, as well as mullite $\left(3 \mathrm{Al}_{2} \mathrm{O}_{3} .2 \mathrm{SiO}_{2}\right)$, colloidal silica $\left(\mathrm{SiO}_{2}\right)$, and electrofused silica $\left(\mathrm{SiO}_{2}\right)$. Each component has been used according to its specific function that provides properties to the ceramic shell to withstand high temperatures, be totally inert chemically and physically, without porosity, and impermeable (PRASAD, 2012; PATTNAIK et al., 2012).

Colloidal silica is one of the main components and it is essential in the formulation of the ceramic shell, acting as a cementing material. This constituent is nothing more than a solution of amorphous silica dispersed in water (silica content around $30 \%$ ), with particle sizes that vary from 0.001 to $1 \mu \mathrm{m}$, and results in a high surface area/volume ratio (ISMAEL et al., 2007). Its production is usually carried out in aqueous solutions of sodium silicate with ion exchange resins. Thus, the particle is negatively charged, and due to its high surface area, these characteristics cause the particles to remain dispersed in the water (PETERS and TWAROG, 1992; PRASAD, 2012; PATTNAIK et al., 2012; LEONARDO, 2013).

The waste generated in the precision casting process, in most cases, is temporarily kept in provisional spaces in the same company that originates it before it is sent to an industrial landfill or for applications in the sub-product condition (downcycling) as material for drainage (CAMACHO et al., 2017). Thirty five percent of precision casting companies are located in the south and southeast regions of Brazil and the volume of CSW generated may fluctuate between 50 and 100 ton per month (LACERDA et al., 2011; APL, 2014).

However, the recycling of CSW may be an environmentally interesting alternative as a way to reintroduce the materials present in it through the return to the own process (PETERS and TWAROG, 1992; BOBROWSKI et al., 2010; DRAJEWICZ and PYTEL, 2012). Thus, it minimizes the extraction of non-renewable natural resources and adds value to the waste, using it in the recycled form as raw material in the development of new products (VALENZA et al., 2010; MACHADO, 2013; NOVAES DE OLIVEIRA et al., 2014).

Therefore, this work aims to present the detailed characterization (physical, chemical, mineralogical and thermal) of the raw materials that compose the ceramic shell used as a mold in the precision casting industry, as well as the sintered ceramic shell, transformed into waste (CSW) after demoulding the cast, in order to verify possible phase changes that make its recycling feasible or not.

\section{MATERIALS AND METHODS 2.1 Waste generation process in study}

The mullite is used in greater quantities in the composition of the ceramic shell in the precision casting process due to its high melting point, resistance to high temperatures, high refractoriness, and good thermal and chemical stability. It presents low density $\left(\sim 3.17 \mathrm{~g} \cdot \mathrm{cm}^{-3}\right)$, low thermal conductivity $\left(\mathrm{k}=2.0 \mathrm{Wm}-1 \cdot \mathrm{K}^{-1}\right)$, low thermal expansion $\left(20 / 200^{\circ} \mathrm{C}=4 \times 106 \cdot \mathrm{K}^{-1}\right)$ (LIAO et al., 2011), and low dielectric constant $(\varepsilon=6.5$ MHz) (SCHNEIDER, 1990; ZHAO et al., 2003).

As shown in Figure 1, the confection of the ceramic shell is performed in eight steps. In the first step, the production of the model is carried out. It is produced in wax, which constitutes a copy of the raw metallic piece to be obtained by leakage of the cast in the ceramic shell (MACHADO, 2001; PRASAD, 2012). Then, the assembly of the cluster is performed when the wax injected models are accommodated in feeding channels, which are specially developed and coupled to a central body, or filling channel, also made of wax (BLACK et al., 1988; PRASAD, 2012). The ceramic coating occurs after the fabrication of the cluster, where it is immersed in a tank containing special ceramic sludge. The plastering process is then carried out by gravity, with controlled granulometry, and, then, the cluster is exposed to a rain of refractory material. The cluster is dried, and the plastering process repeats itself countless times until the covering possesses specific conditions to receive the liquid metal. The first layer of clay and refractory materials is the thinnest, made of silica (colloidal and electrofused) and zirconite (zirconium flour), as it forms the inner face, reproducing all the details of the model, including its flat surface (MACHADO, 2001, MACHADO, 2005; PRASAD, 2012). Under constant temperature and pressure, the cluster is placed in an autoclave at $\approx 180^{\circ} \mathrm{C}$, where the dewaxing occurs, leaving the ceramic shell empty, and liberating space with the desired shape to be filled by the molten metal (PRASAD, 2012). The calcination of the ceramic shell is performed in a high temperature oven (900 to $1050{ }^{\circ} \mathrm{C}$ ) for the removal of all organic matter. 
Nevertheless, it can still be present internally in the models and channels of the cluster, which allows its thermal adequation (MACHADO, 2001; PRASAD, 2012). Then, the leakage of liquid metal at temperatures of 1500 to $1600{ }^{\circ} \mathrm{C}$ occurs.

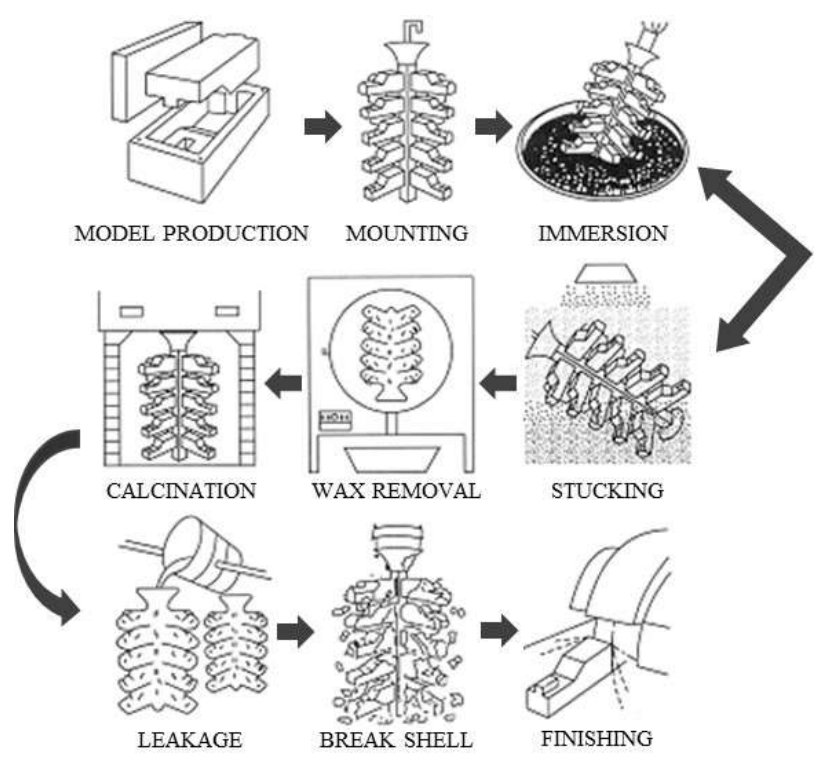

Figure 1. Steps of the ceramic shell waste generation process in the precision casting process in study. Source: Adapted from Prasad (2012)

After the cooling and solidification of the metal, the breaking of the ceramic shell is performed, generating the solid waste called Ceramic Shell Waste (CSW).

\subsection{Materials}

The refractory ceramic raw materials and the CSW were supplied by a precision casting company located in the northern region of Rio Grande do Sul, Brazil. The raw materials characterized in this study were: chamottes (thick and fine), mullite, zirconium sand and flour, and the silicas (colloidal and electrofused).

The CSW sampling was carried out according to NBR 10007 (ABNT, 2004) and the raw waste of ceramic shell is shown in Figure 2 . It is presented as being a material of light coloration on the outside with different dimensions (between 2 and $20 \mathrm{~cm}$ ), which vary due to the size of the part to be produced. The inside of the CSW is characterized by a darker coloration, as it is the side that has direct contact with the molten liquid metal that solidifies.

The disintegration process of the CSW constituents was performed as shown in the flowchart of Figure 3. First, the CSW was disaggregated in a jaw mill. Then, a roller mill was used to disaggregate the fragments of larger particles remaining from the first disintegration, and, finally, a third grinding was performed using a ball mill for 30 minutes. The powdery CSW material of particle size lower than $38 \mu \mathrm{m}$ was characterized, and is also shown in Figure 3.

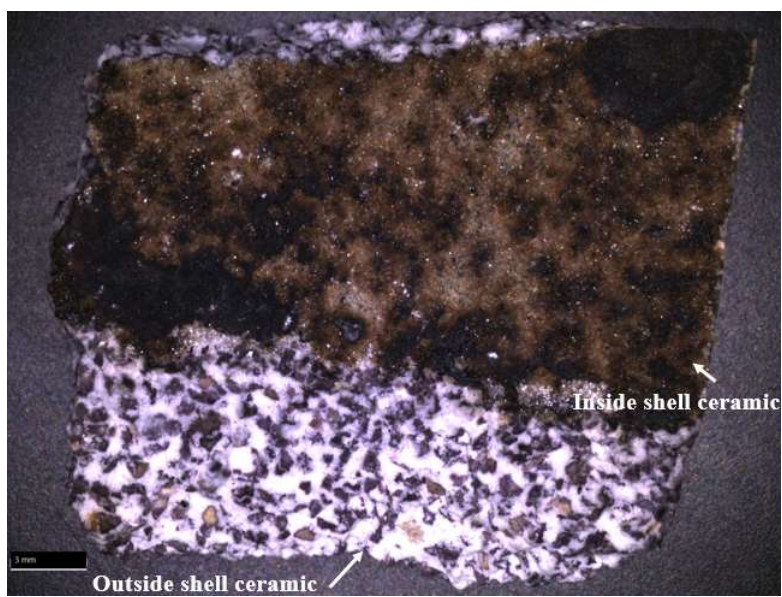

Figure 2. Ceramic shell waste (CSW). Source: authors

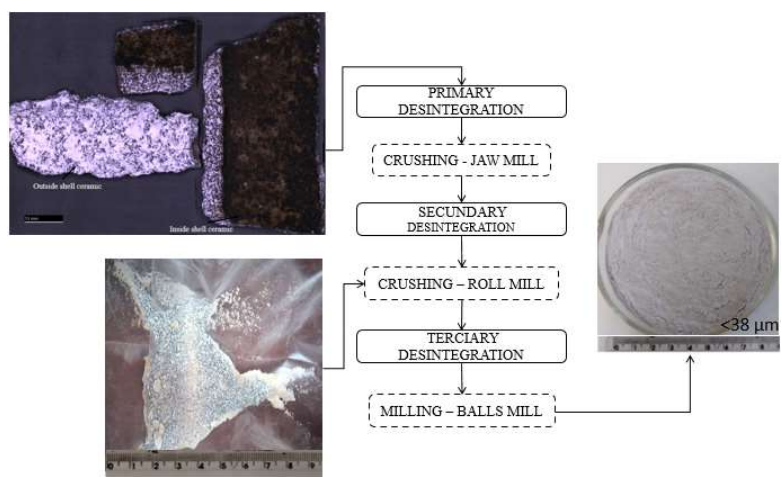

\subsection{Characterization methods \\ 2.3.1 Analysis of particle size distribution}

The medium diameter of the materials was determined with a laser particle size analyzer, from MICROTRAC, model S3500. The experiment was performed by wet method, according to Standard 13320 (ISO, 2009) run time was of 20 seconds for all the samples and system flow varying from 25 to $50 \%$. Information, such as refractive index, was researched for each sample: a. electrofused silica: 1.46 ; b. zirconium flour and sand: 1.92; and c. mullite, fine and thick chamotte: 1.81 . The shape of the particle for all the samples was considered as irregular, and the refractive index of the fluid used, water, was of 1.33 . 


\subsubsection{Specific mass and surface area}

The specific mass of the materials was determined in a helium gas pycnometer (using MICROMERITICS, model ACCUPYC 1340) after the removal of the humidity from the samples, at 105 ${ }^{\circ} \mathrm{C}$. The specific surface of the materials was determined by the BET method (Branauer, Emmett and Teller), in an equipment from MICROMERITICS, model Tristar Plus II. For this technique, the samples were prepared under vacuum at a temperature of $200{ }^{\circ} \mathrm{C}$ for 48 hours for total outgassing (MICROMERITICS, 2016).

\subsubsection{Chemical characterization}

The chemical composition was determined by Xray fluorescence spectrometry. The software used for the quantification was OMNIAN 37, through equipment PANalytical, model Axios, and the L.O.I. (Loss on Ignition) organic fraction was determined by approximately one gram of sample in an oven at $110{ }^{\circ} \mathrm{C}$ for 4 hours, weighed, and then calcinated in a muffle oven at a temperature of $1000{ }^{\circ} \mathrm{C}$.

\subsubsection{Mineralogical characterization}

The mineralogical technique used was X-Ray Diffraction for the identification of the crystalline phases (equipment PANalytical, model X'Pert PRO, with software X'Pert HighScore from Philips). The diffractograms were analyzed between 4 and $90^{\circ}$, in the following conditions: scanning by steps of $0.0262606 ; 0.033453{ }^{\circ} \mathrm{C} \cdot \mathrm{s}^{-1}$ speed; Cu Ka radiation; graphite monochromator to remove $\mathrm{KB}$ radiation and use of 255 channels to identify crystallites. The samples were ground in a Retsch automatic agate graal for 20 minutes to reduce the particle size until they reached a size inferior to $38 \mu \mathrm{m}$.

\subsubsection{Thermal characterization}

The thermal decomposition of the raw materials was investigated separately through the behavior by differential thermal analysis (DTA), since the recycling of CSW, containing crystalline silica in the shape of cristobalite, is compromised. Another important factor to be considered is that, during the drying stages of the ceramic shell, before it becomes waste (CSW), the water present is released, and changes in expansion and thermal capacity can be understood through the phase transformations of the amorphous silica present in the composition of the material (BRAGANÇA and BERGMANN, 2010; LIAO et al., 2011).

To investigate the crystallization temperature, the materials were subjected from room temperature to $1500{ }^{\circ} \mathrm{C}$, with a heating rate of 10 ${ }^{\circ} \mathrm{C} \bullet \mathrm{min}^{-1}$ under nitrogen gas atmosphere (N2). The simultaneous thermal analysis equipment used was from PerkinElmer, model STA 8000.

\section{RESULTS AND DISCUSSIONS}

Laser granulometry is presented in Table 1.

The zirconium flour (Daverage $=19.47 \mu \mathrm{m})$, electrofused silica (Daverage $=38.17 \mu \mathrm{m})$, and the mullite (Daverage $=54.39 \mu \mathrm{m})$ are the materials more finely employed in the confection of the ceramic shell as a refractory mold (Figure 4). The zirconium sand $($ Daverage $=163.10 \mu \mathrm{m})$ presents an intermediate particle size to the mentioned group and chamottes, being the fine (Daverage = $541.40 \mu \mathrm{m})$ and the thick (Daverage $=780.20 \mu \mathrm{m})$, which are the materials used in higher quantity and that guarantee a minimum porosity of the ceramic shell in the final process.

These chamottes, together with the other raw materials, have the function of acquiring sufficient permeability for the escape of the gases (AMIRA, DUBÉ, and TREMBLAY, 2011), conductivity, and low thermal expansion, which keeps the heat transfer through the walls of the mold so as to allow the cooling of the metal and, at the end, facilitate its removal (PATTNAIK et al., 2012; PRASAD, 2012; LEONARDO, 2013).

Table 1. Equivant diameter by laser diffraction of the raw materials used in the confection of the ceramic shell

\begin{tabular}{|l|c|c|c|c|}
\hline Raw materials & $\begin{array}{c}\mathbf{D}_{10} \\
(\boldsymbol{\mu m})\end{array}$ & $\begin{array}{c}\mathbf{D}_{50} \\
(\boldsymbol{\mu m})\end{array}$ & $\begin{array}{c}\mathbf{D}_{90} \\
(\boldsymbol{\mu m})\end{array}$ & $\begin{array}{c}\mathbf{D}_{\text {average }} \\
(\boldsymbol{\mu \mathrm { m }})\end{array}$ \\
\hline Electrofused sílica & 4.77 & 30.15 & 98.86 & 38.17 \\
\hline Mullite & 8.87 & 42.47 & 128.0 & 54.29 \\
\hline Fine chamotte & 382.9 & 528.1 & 740.9 & 541.4 \\
\hline Thick chamotte & 469.6 & 794.4 & 1069 & 780.2 \\
\hline Zirconium sand & 109.4 & 160.0 & 226.6 & 163.1 \\
\hline Zirconium flour & 2.988 & 17.55 & 43.49 & 19.47 \\
\hline
\end{tabular}




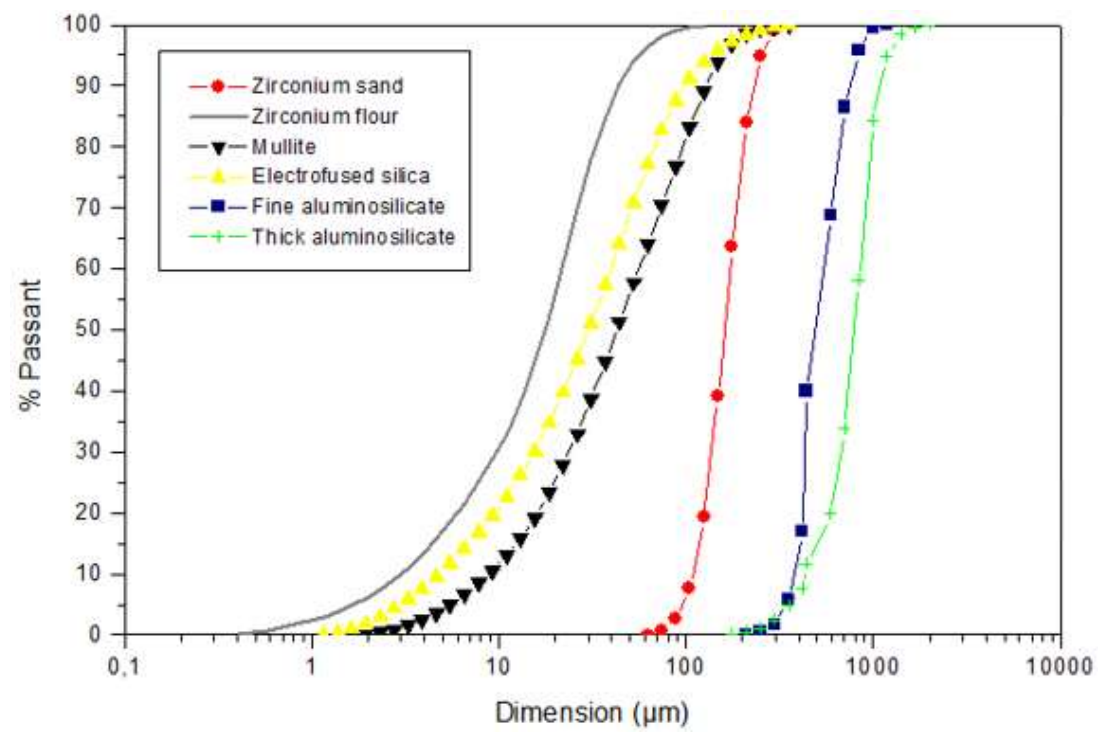

Figure 4. Disintegration process of the CSW. Source: authors

These refractory materials are used in the process due to being oxides with high purity and its respective particle sizes are limited by the superficial details of the part to be produced. These finely ground powders are used in a specific range of size that varies from 45 to $150 \mu \mathrm{m}$, and are predominantly small, with particles that extend up to a colloidal size range (11 to $16 \mathrm{~nm}$ ) (PETERS and TWAROG, 1992; PRASAD, 2012).
Figure 5 presents the values found for the analyses of specific mass and surface area for the raw materials individually. As well as the result of laser granulometry shown, the specific mass presents a variation from 2.1908 to $4.4474 \mathrm{~g} \cdot \mathrm{cm}^{-}$ ${ }^{3}$, and the specific surface is relatively low, below $3 \mathrm{~m}^{2} \cdot \mathrm{g}^{-1}$, which shows the predominant characteristic of refractory ceramic materials (MALENSEK et al., 2015).

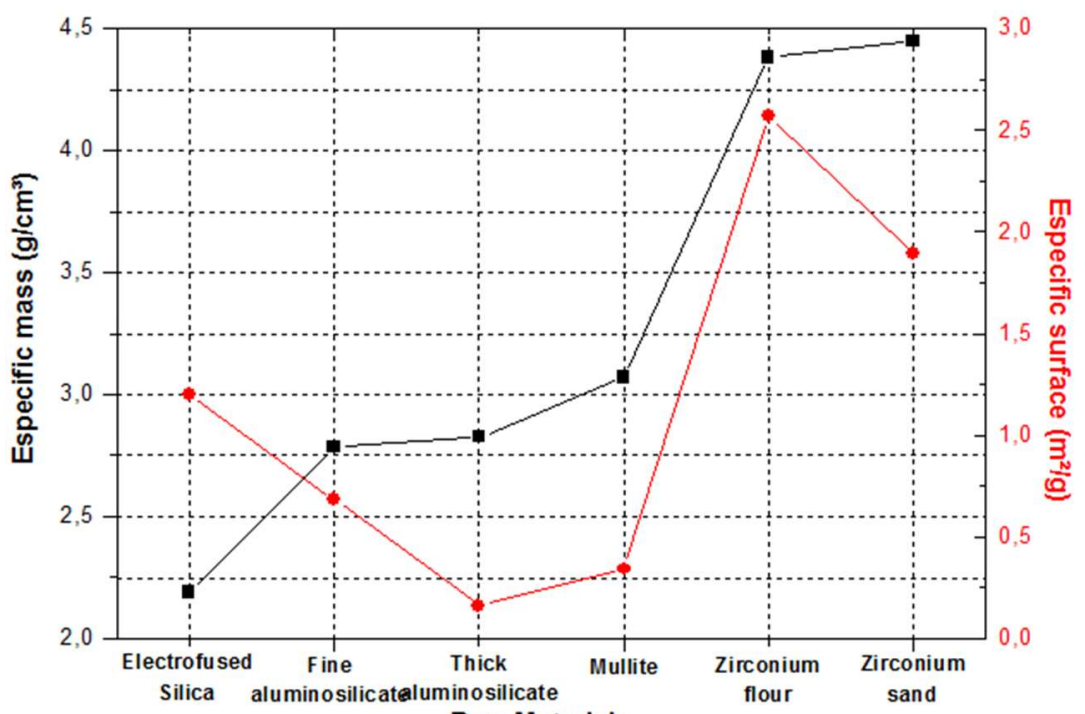

Figure 5. Relation between specific mass and specific surface of the raw materials

Electrofused silica is the component with the lowest specific mass among all the raw materials $\left(2.1908 \mathrm{~g} \cdot \mathrm{cm}^{-3}\right)$, while the aluminosilicates (fine and thick chamottes and mullite) present intermediate values. The zirconium flour and sand showed specific mass above $4 \mathrm{~g} \cdot \mathrm{cm}^{-3}$, that is, components with the highest specific mass. Furthermore, these components showed the larger surface areas, in relation with the other components, 2.9107 and $2.2402 \mathrm{~m}^{2} \cdot \mathrm{g}^{-1}$, respectively, since zirconium flour is the constituent used in the first layer, and the one that stays in direct contact with the molten 
metal. This fact confirms and corroborates with the smallest average particle diameter found, $17.55 \mu \mathrm{m}$. The first layer in the confection of the ceramic shell needs to have great interaction with the subsequent layers, and the coating materials responsible for refractoriness and permeability, such as the mullite, fine chamotte and thick chamotte, are characterized with the surface area values of $0.3164,0.6769$ and $0.7501 \mathrm{~m}^{2} \cdot \mathrm{g}^{-1}$, respectively. These make up the ceramic mold in order to guarantee low porosity, thermal and chemical inertia, among other properties (AMIRA, DUBÉ, and TREMBLAY, 2011; LEONARDO, 2013).

The aluminosilicates showed values below $1 \mathrm{~m}^{2} \bullet \mathrm{g}$ 1 of surface area, and the electrofused silica showed an intermediate value to the zirconium flour and sand. According to Ismael et al. (2007), colloidal silica may present around $220 \mathrm{~m}^{2} \bullet \mathrm{g}^{-1}$, considered as the component with larger surface area in the ceramic shell. The ground CSW showed specific mass of $2.9284 \mathrm{~g} \cdot \mathrm{cm}^{-3}$, as this result ends up being an average that represents the percentages used of each raw material in its composition.

The results of XRF and the organic matter content (L.O.I) are shown in Table 2.

Table 2: Elementary chemical composition in the form of more stable oxide by XRF in \%

\begin{tabular}{|c|c|c|c|c|}
\hline Materials & $\mathrm{SiO}_{2}$ & $\mathrm{Al}_{2} \mathrm{O}_{3}$ & $\mathrm{ZrO}_{2}$ & L.O.I. \\
\hline Electrofused sílica & 99.0 & 0.24 & - & 0.40 \\
\hline Mullite & 29.23 & 68.96 & - & 0.03 \\
\hline Fine chamotte & 25.73 & 65.42 & 2.0 & 0.24 \\
\hline Thick chamotte & 29.48 & 63.39 & 1.97 & 0.22 \\
\hline Zirconium sand & 25.84 & 5.60 & 68.73 & 0.56 \\
\hline Zirconium flour & 25.75 & 5.48 & 68.21 & 1.46 \\
\hline CSW & 48.55 & 41.33 & 6.05 & 0.15 \\
\hline Materials & \multicolumn{4}{|c|}{ Oxides in the form $<2 \%$ trace } \\
\hline Electrofused sílica & \multicolumn{4}{|c|}{$\begin{array}{l}\mathrm{Na}_{2} \mathrm{O}, \mathrm{MgO}, \mathrm{P}_{2} \mathrm{O}_{5}, \mathrm{~K}_{2} \mathrm{O}, \mathrm{CaO}, \mathrm{TiO}_{2}, \\
\mathrm{MnO}\end{array}$} \\
\hline Mullite & \multicolumn{4}{|c|}{$\mathrm{Na}_{2} \mathrm{O}, \mathrm{MgO}, \mathrm{CaO}, \mathrm{TiO}_{2}, \mathrm{Fe}_{2} \mathrm{O}_{3}$} \\
\hline Fine chamotte & \multicolumn{4}{|c|}{$\begin{array}{l}\mathrm{Na}_{2} \mathrm{O}, \mathrm{MgO}, \mathrm{K}_{2} \mathrm{O}, \mathrm{CaO}, \mathrm{TiO}_{2}, \mathrm{MnO}, \\
\mathrm{Fe}_{2} \mathrm{O}_{3}, \mathrm{HfO}_{2}\end{array}$} \\
\hline Thick chamotte & \multicolumn{4}{|c|}{$\begin{array}{l}\mathrm{Na}_{2} \mathrm{O}, \mathrm{MgO}, \mathrm{K}_{2} \mathrm{O}, \mathrm{CaO}, \mathrm{TiO}_{2}, \mathrm{MnO}, \\
\mathrm{Fe}_{2} \mathrm{O}_{3}, \mathrm{HfO}_{2}\end{array}$} \\
\hline Zirconium sand & \multicolumn{4}{|c|}{$\mathrm{Fe}_{2} \mathrm{O}_{3}, \mathrm{HfO}_{2}, \mathrm{MgO}, \mathrm{Y}_{2} \mathrm{O}_{3}, \mathrm{NbO}$} \\
\hline Zirconium flour & \multicolumn{4}{|c|}{$\mathrm{Fe}_{2} \mathrm{O}_{3}, \mathrm{HfO}_{2}, \mathrm{MgO}, \mathrm{Y}_{2} \mathrm{O}_{3}, \mathrm{NbO}$} \\
\hline CSW & \multicolumn{4}{|c|}{$\begin{array}{l}\mathrm{Na}_{2} \mathrm{O}, \mathrm{MgO}, \mathrm{K}_{2} \mathrm{O}, \mathrm{CaO}, \mathrm{TiO}_{2}, \mathrm{MnO}, \\
\mathrm{Fe}_{2} \mathrm{O}_{3}, \mathrm{HfO}_{2}\end{array}$} \\
\hline
\end{tabular}

The XRF reference standard used for the quantification presents the analysis in the form of more stable binary oxides, in which, according to MACHADO (2005) and MACHADO (2013), the Si, Al and $\mathrm{Zr}$ elements are major in the composition of the CSW, and form aluminosilicates, and zirconium silicates in the mullite, fine and thick chamotte, and zirconium flour and sand raw materials. It is verified that the aluminum element, in the form of the more stable oxide $\left(\mathrm{Al}_{2} \mathrm{O}_{3}\right)$, is major in the raw materials: mullite, fine and thick chamotte; and the zirconium element, in the form of the more stable oxide $\left(\mathrm{ZrO}_{2}\right)$ is major in the raw materials: zirconium flour and sand. The elements $\mathrm{Y}, \mathrm{Nb}$ and $\mathrm{Hf}$, represented in oxides $\mathrm{Y}_{2} \mathrm{O}_{3}, \mathrm{NbO}$ e $\mathrm{HfO}_{2}$, can be characteristic contaminations normally found in the zircon mineral, a crystalline compound such as zirconium silicate $\left(\mathrm{ZrSiO}_{4}\right)$, which is rich in igneous rocks and, in some cases, tends to incorporate inclusions (SABEDOT et al., 2009). The zirconium silicate $\left(\mathrm{ZrSiO}_{4}\right)$ is very common in igneous and metamorphic rocks, when used with $98 \%$ purity it can also be a host for a significant part of the uranium, thorium, hafnium, and other rare earth metals rocks (LEE, 2005; WILSON et al., 2011). Most of the impurities is composed of hafnium silicate, which is chemically identical to zirconium silicate up to $\approx 1627{ }^{\circ} \mathrm{C}$ (CARUBA et al., 1985; WILSON et al., 2011).

It is possible to verify the crystalline phases in the raw materials, according to the diffractograms presented in Figure 6. The electrofused silica is clearly in the amorphous form, corroborating with its obtaining method and the extremely high silica content, as well as the colloidal silica, also in the amorphous form. Zirconium flour and sand were presented in the crystalline form and differ only by the size of the particles in the stages of the precision casting process. In both were identified only one crystalline phase, the zirconium silicate $\left(\mathrm{ZrSiO}_{4}\right)$, commonly called zircon. In the mullite and the fine and thick chamotte raw materials, which also differentiate by the size of the particles, it was identified only the mullite crystalline phase $\left(3 \mathrm{Al}_{2} \mathrm{O}_{3} \cdot 2 \mathrm{SiO}_{2}\right)$. 


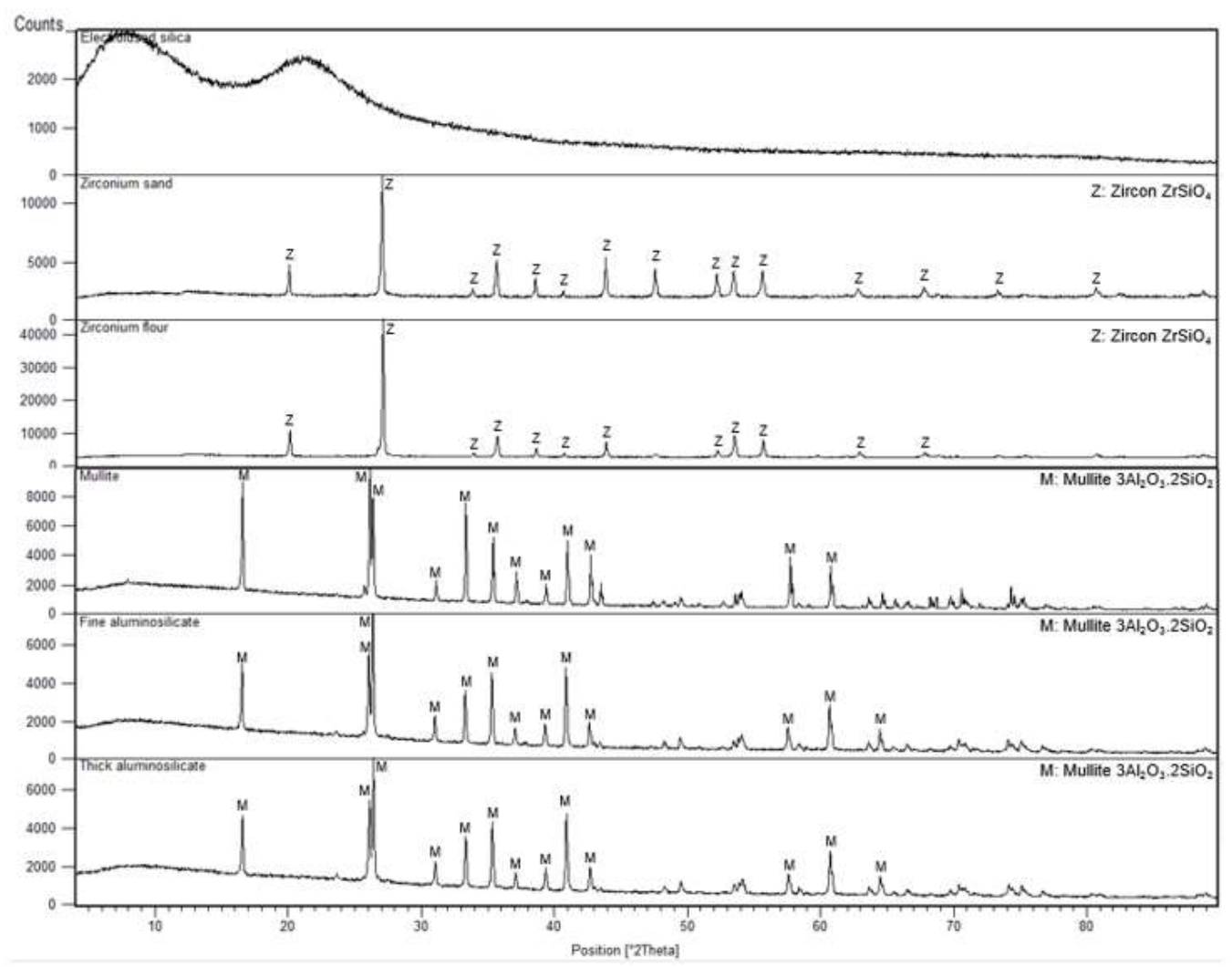

Figure 6. Diffractograms of the raw materials

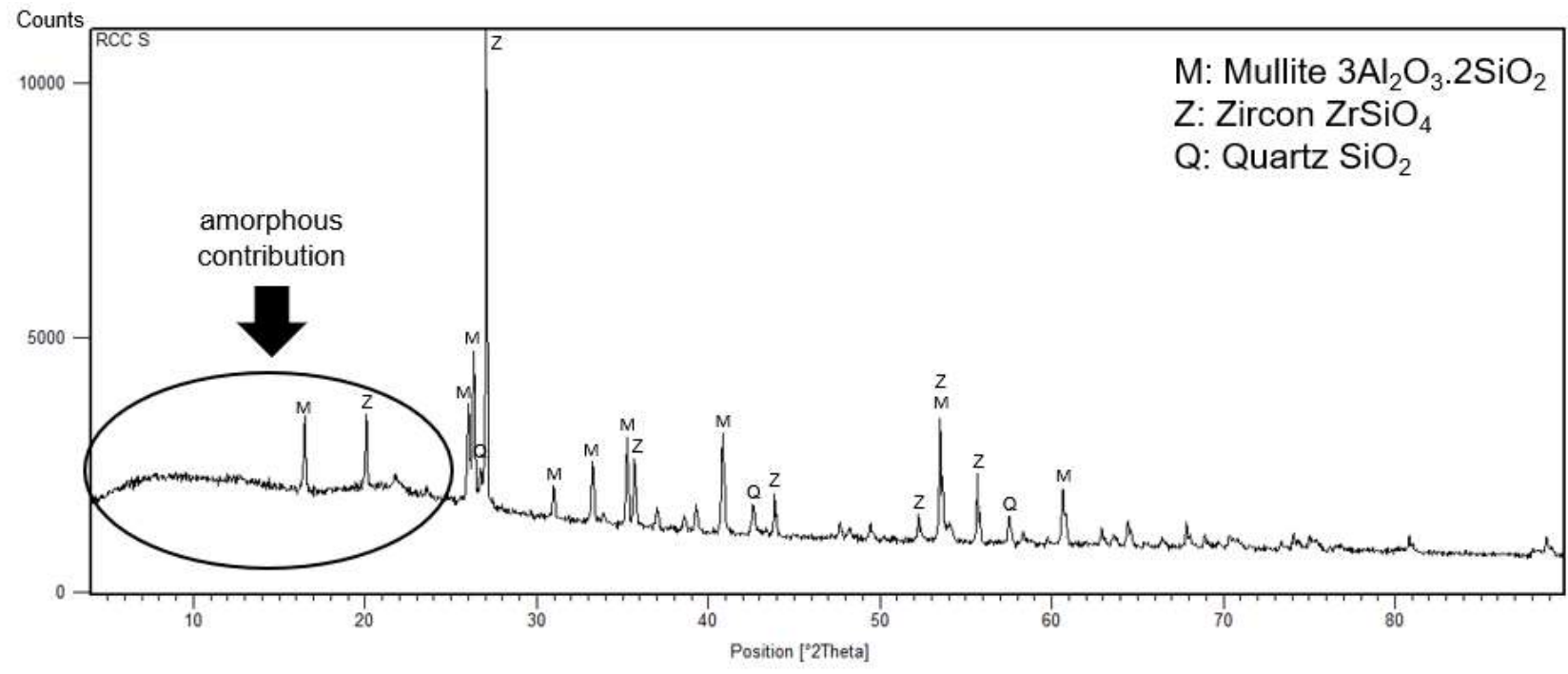

Figure 7. Diffractogram of the ceramic shell waste

The CSW diffractogram (Figure 7) showed the zircon crystalline phases (zirconium silicate $\left.\mathrm{ZrSiO}_{4}\right)$, mullite $\left(3 \mathrm{Al}_{2} \mathrm{O}_{3} \cdot 2 \mathrm{SiO}_{2}\right)$ and silica in the form of quartz $\left(\mathrm{SiO}_{2}\right)$. Thus, it is clear that the only raw materials that had taken phase transformations in their structure were the colloidal silica and electrofused silica, which went from the amorphous structure to the crystalline phase of quartz. In the diffractogram, a characteristic amorphous behavior is perceived between the angles of 5 and $25^{\circ}$, approximately, with detachment from the baseline, which indicates that some fraction remained amorphous. This detachment of the baseline is also verified in the raw materials corresponding to the aluminosilicates: mullite, fine chamotte, and thick chamotte, however, only up to the angle of $15^{\circ}$. 
The results on the isolated investigation of the phase evolution in the raw materials through the behavior by differential thermal analysis (DTA) are presented, as shown in Figure 8, in the raw materials zirconium sand $\left(\mathrm{ZrSiO}_{4}\right)$, zirconium flour $\left(\mathrm{ZrSiO}_{4}\right)$, chamotte $\left(3 \mathrm{Al}_{2} \mathrm{O}_{3} .2 \mathrm{SiO}_{2}\right)$, mullite $\left(3 \mathrm{Al}_{2} \mathrm{O}_{3} \cdot 2 \mathrm{SiO}_{2}\right)$, electrofused silica $\left(\mathrm{SiO}_{2}\right)$ and $\mathrm{CSW}$.
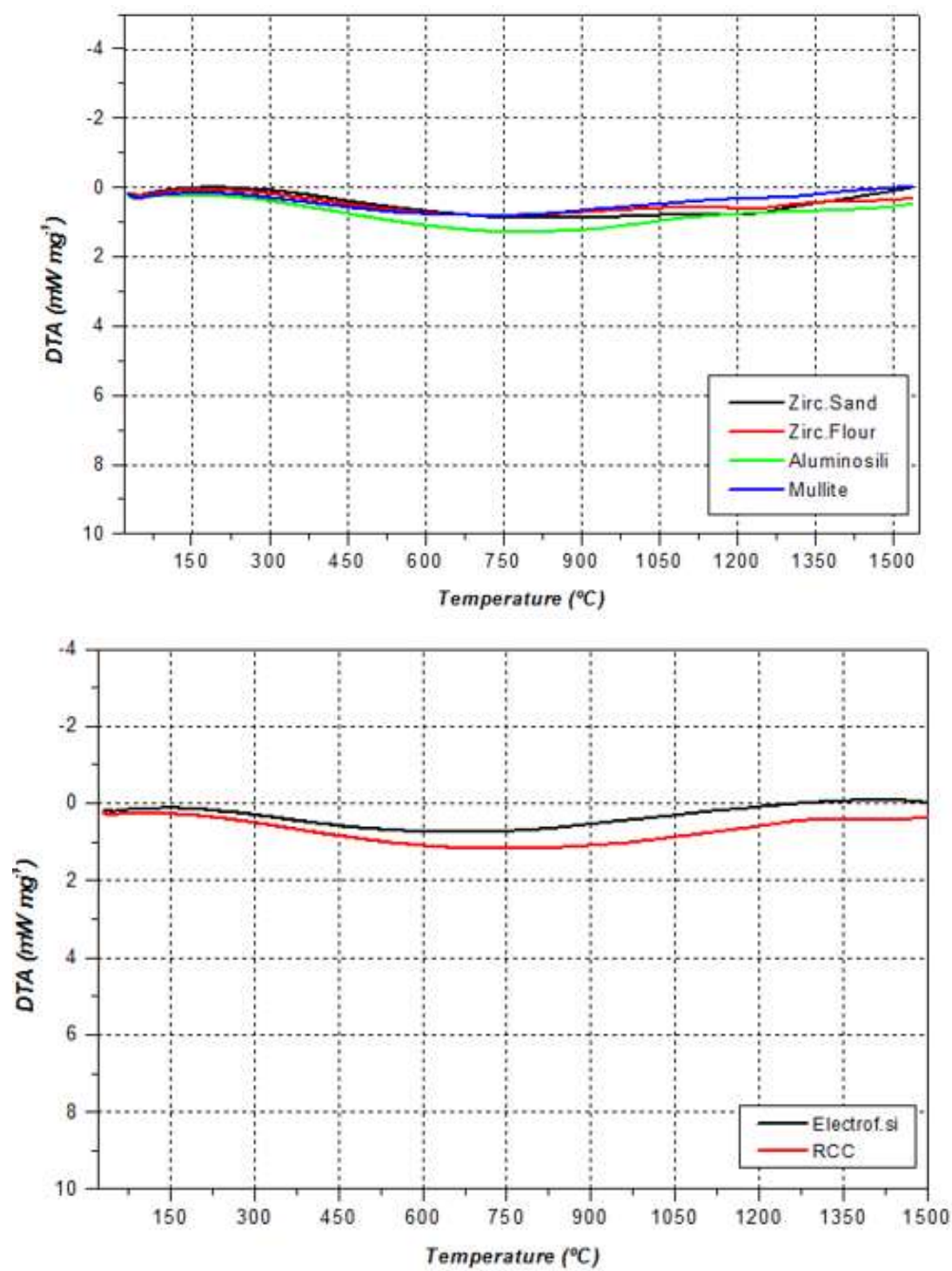

Figure 8. DTA results in the refractory raw materials (Zirconium sand, zirconium flour, aluminosilicates, mullite, electrofused silica) and CSW from 20 to $1500^{\circ} \mathrm{C}$ (both with a heating level of $10^{\circ} \mathrm{C} \cdot \mathrm{min}^{-1}$

According to the thermal analysis performed, there is no confirmation that phase changes could occur in the crystalline structure of these individually analyzed raw materials, because the materials do not present energy absorption or release during heating, which is verified in the behavior along the increase of temperature. This same behavior can be observed in the electrofused silica raw material, which, according to the diffractogram performed, presented amorphous structure, and did not present structural change until up to the analyzed temperature.

However, for the same analysis performed (DTA) in the colloidal silica raw material (Figure 9) at $\approx$ $100{ }^{\circ} \mathrm{C}$, occurred an endothermic reaction, which is verified by the loss of water, since it is a ceramic material in suspension, and at the temperature of $\approx 940{ }^{\circ} \mathrm{C}$ occurred an exothermic reaction, which, according to Reddy (2004), at temperatures close to $900{ }^{\circ} \mathrm{C}$, this phenomenon can be associated to a phase transformation of the silica from the amorphous structure to the crystalline quartz structure. 


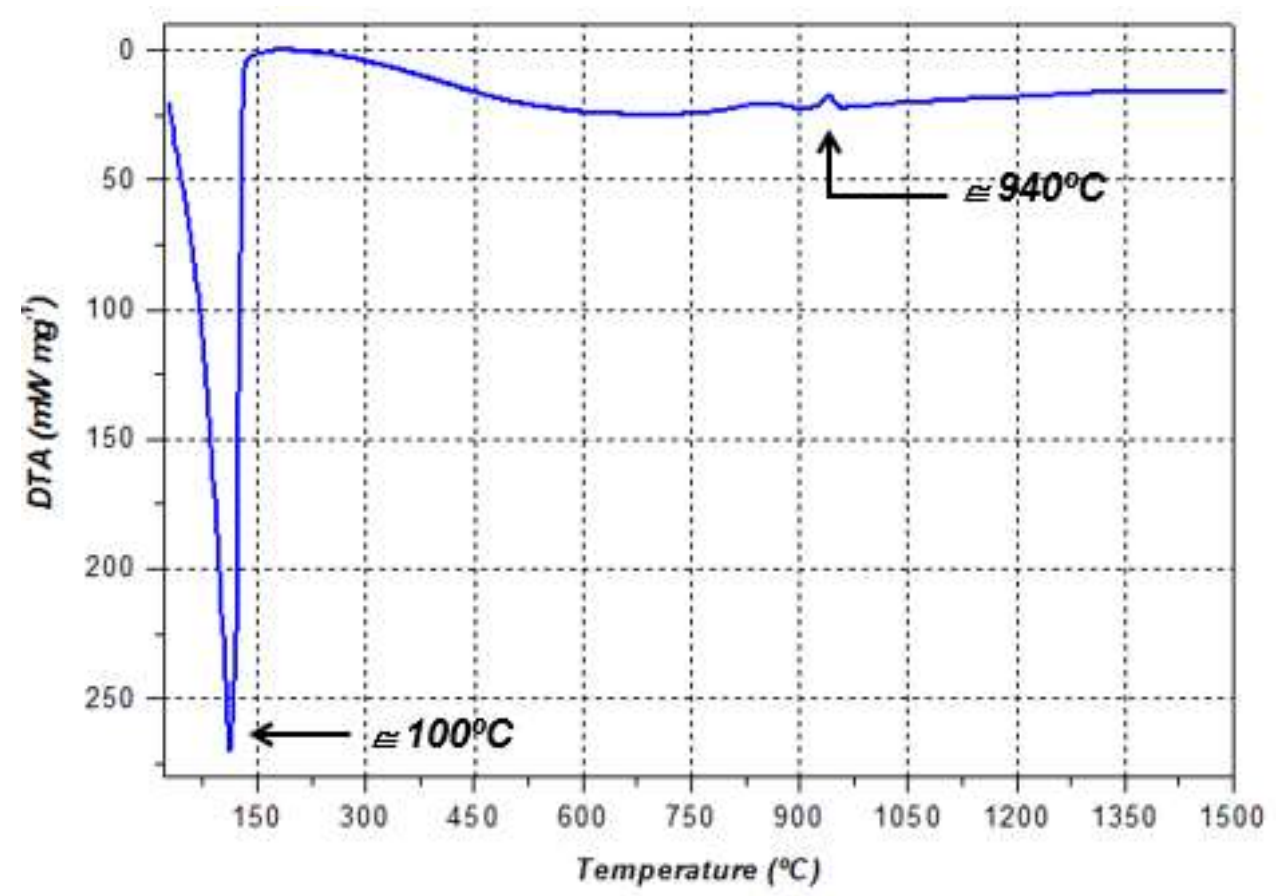

Figure 9. DTA results for the colloidal silica raw material from 20 to $1500^{\circ} \mathrm{C}$ (both with a heating level of $10^{\circ} \mathrm{C} . \mathrm{min}^{-1}$ )

When analyzing the CSW, it was observed that it did not present energy absorption or release in the thermal analysis and, consequently, there was no formation of new crystalline phases. According to Bragança and Bergmann (2010), in order to reorganize its structure in the form of silica, a large quantity of activation energy would be necessary to break the $\mathrm{Si}-\mathrm{O}-\mathrm{Si}$ bonds and realign the $\mathrm{SiO}_{4}^{-4}$ coordination units (Figure 9).

As shown in the thermal analyses (DTA), the thermal properties analyzed in isolation remain unchanged in the raw materials, except for the colloidal silica, which crystallizes. When analyzing the CSW, containing all the composition of the raw materials, it is evidenced that part of the silica present in its composition crystallizes, as verified in the XRD analysis in the quartz crystalline form. This contribution proves that the silica fraction that crystallizes is associated to the colloidal silica raw material and does not correspond to the electrofused silica raw material. According to Xu (2015) and Xu, Lekakh and Richards (2016), reusing any fraction of crystalline silica would severely weaken the ceramic shell, because during the cooling of the molten metal, abrupt volume changes occur due to the phase transformations from alpha to beta in the silica raw materials. According to Kazemi et al. (2013), the presence of cristobalite in any reformulation in the composition of the recycled ceramic shell undergoes a phase transformation with a $5 \%$ volume contraction, decreasing the flexural resistance of the recycled materials.
According to Pattnaik (2017), the properties of the ceramic shell, such as increase of the tensile resistance and decrease of the porosity and permeability, can be improved through the addition of natural agents in the sludge that contain the colloidal silica raw material, during the diving stages of the cluster, which decreases repairs on the shell, and avoids cracks caused by it.

Therefore, originates the possibility to analyze a technology that defines recycling parameters for the CSW. An alternative is shown for separating the still intact noble materials and that do not undergo phase transformations, such as the chamottes and the components of zirconium that have higher aggregated value, which raises an alternative for recycling within the production process itself. Thus, the pollution control shifts to its prevention, in order to avoid that noble materials that present potential for use are discarded without any kind of recycling. This avoids transportation and final disposal costs, besides the incalculable environmental gain through the use of non-renewable natural resources.

As Brazil has considerable mineral potential, due to its great territorial extension, this fact has been important to develop studies on mineral recycling and waste treatment (SOUZA and MANSUR, 2004). With the extracted minerals getting increasingly scarce, and, consequently, greater volumes of waste generated, it is necessary to work in a variety of subjects to offer 
a pro-active multidisciplinary approach for the recycling of noble materials present in the CSW, since many areas can benefit from it (EDRAKI et al., 2014; ALVES et al., 2016; CAMACHO, 2017).

\section{CONCLUSIONS}

The physical, chemical, mineralogical and thermal characterization results in the raw materials and CSW, considering the data obtained through the materials characterization techniques, such as particle size distribution, specific mass determination by helium gas pycnometry, measurement of surface area by the BET method, X-ray fluorescence, X-ray diffraction and differential thermal analysis, allowed the following considerations:

- As for the distribution of particle size, the zirconium flour, electrofused silica, and mullite raw materials are the materials more finely employed in the confection of the ceramic shell as a refractory mold, with average sizes of 19.47 , 38.17 and $54.39 \mu \mathrm{m}$, respectively. The zirconium sand and chamotte raw materials have average particle sizes of 163.10 and $541.40 \mu \mathrm{m}$. The specific mass results indicated that the zirconium flour and sand are the materials with the higher values of $\approx 4.5 \mathrm{~g} \bullet \mathrm{cm}^{-3}$, and for the CSW it was

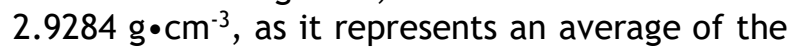
percentages used of each raw material in its composition. In relation to surface area, all the raw materials showed characteristic low values of refractory ceramic materials.

- The chemical analysis of the CSW showed the presence of the major elements ( $\mathrm{Al}, \mathrm{Si}$ and $\mathrm{Zr}$ ) and the trace elements present in the raw materials, demonstrating correlation with the crystalline compounds identified in the X-ray diffraction analyses.

- Based on X-ray diffraction results, it was noted that the two raw materials that are in the clearly amorphous structure correspond to colloidal silica and electrofused silica; however, in the thermal analysis, only the colloidal silica clearly showed some structural phase change. Analyzing the CSW, it was noted that, in its diffractogram, part of the silica, probably of the colloidal silica, is that transforms into the quartz crystalline structure, corroborating with the analyzed XRD technique.

- The pertinent results to the investigation in isolation of the phase decomposition in the raw materials that constitute the ceramic mold, through the behavior by differential thermal analysis (DTA), proved to be relevant for the knowledge of the structural behavior of these materials, with the increasing of the temperature.

The mullite, zirconium sand, zirconium flour, and electrofused silica raw materials did not present phase changes in their structures, with the exception of colloidal silica, which may have changed part of its amorphous structure to the quartz crystalline form.

Due to the fact that the crystalline cristobalite phase was not found in the CSW, only part of it in the form of quartz, then comes the possibility to, in the future, analyze a technology that defines recycling parameters for the CSW. Studies that perform analysis and simulation of the precision casting process indicate that the necessary time for solidification is one of the most important predominant factors, and that govern the quality of the casting, having a direct relation with the transformation of the solid state in the cavity of the ceramic mold (DONG et al., 2011; RAFIQUE and IQBAL, 2009). As a general rule, the faster the solidification time, the better is the strength, homogeneity, integrity, and quality of the casting. This is reflected not only in the produced part, but also in the quality of the ceramic mold, which interferes in the structural characteristics of the refractory materials present there. The solidification time can be determined by a combination of heat transfer, and deformation analysis during pouring and solidification of the alloy in the mold cavity. As during casting, the temperature of the mold decreases quickly $(\approx 250$ to 300 seconds) since this interval must be short to make the heat transfer process stable between the pouring and the coating. According to Dong et al. (2011), part of the amorphous silica structure present on the inside of the mold, which presents a higher temperature, can crystallize, and that external fraction of amorphous silica present in the mold, which has a lower temperature, may not crystallize fully.

In general, the investigation carried out on the raw materials shows a great potential for recycling in the production process itself when compared to the investigation of the generated ceramic bark waste. However, the process temperature, around $1500^{\circ} \mathrm{C}$, is not sufficient to change phases in the raw materials analyzed in isolation and, when together, in the form of waste, only phase changes were noticed in the colloidal silica. However, a study of the waste through improvement processes is of great value to reintroduce it into the production process, adding value and avoiding the use of natural resources, since these materials are increasingly scarce in the nature. 


\section{ACKNOWLEDGEMENTS}

The authors thank CAPES for the doctorate grant, and to CNPq (Brazilian National Council for ScientificResearch) for the grants given to some of the authors: Technological Development Research Grants - DT2/CNPq, and Research productivityProductivity Grant PQ2/CNPq.

\section{REFERENCES}

ALVES, H. P. A.; SILVA, J. B.; CAMPOS, L. F. A.;TORRES, S. M.; DUTRA, R. P. S.; MACEDO, D. A. Preparation of mullite based ceramics from claykaolin waste mixtures. Ceramics International, 2016: 42: 19086-19090.

AMIRA, S.; DUBÉ, D.; TREMBLAY, R. Method to determine hot permeability and strength of ceramic shell moulds. Journal of materials processing technology, 2011:211; 1336-1340.

Arranjo Produtivo Local - Metal Mecânico e Automotivo. Plano de Gerencialmento de Resíduos Sólidos. 67 f. 2014. Porto Alegre, RS. Available at : https://sedetur.rs.gov.br/upload/ arqui vos/carga20170527/04092704-1426534450pgrs-apl-metal-mecanico-e-automotivo-rs.pdf.

Access: aug. 2020.

Associação Brasileira de Normas Técnicas (ABNT). NBR 10007: Amostragem de resíduos sólidos. Rio de Janeiro, 2004.

BLACK, J. T.; DEGARMO, E. P.; KOHSER, R. Materials and Processes in Manufaturing. 7th ed. New York, 1988.

BOBROWSKI, A.; DANKO, R.; HOLTZER, M.; ZYCH, $\mathrm{J}$. Reclamation of material from used ceramic moulds applied in the investment casting technology. Archives of foundry engineering, 2010;10:199-204.

BRAGANÇA, S. R.; BERGMANN, C. P. Materiais de construção civil e princípios de ciência e engenharia de materiais. Ed. G. C. Isaia. 2.ed. São Paulo. Cap. 20, p. 1712. IBRACON, 2010.

CAMACHO, A. L. D.; MORAES, C. A. M.; MODOLO, R. E. Caracterização térmica e estrutural de casca cerâmica utilizada no processo de fundição. CONAF, 2017. $17^{\circ}$ Congresso Abifa de Fundição, 26-29 sept., 2017. São Paulo, SP, Brazil.

CAMACHO, A. L. D. Caracterização e valorização de material casca cerâmica gerado no processo de fundição de precisão. 2017. 142 p. Dissertation (Masters in Civil Engineering). Universidade do Vale do Rio dos Sinos, São Leopoldo, 2017.
CARUBA, R.; BAUMER, A.; GANTEAUME, M.; LACCONI, P. An experimental study of hydroxyl groups and water in synthetic and natural zircons: a model of the metamict state. Am Miner, 1985; 70: 1224-1231.

DONG, Y., BU, K.; DOU, Y.; ZHANG, D. Determination of interfacial heat-transfer coefficient during investment-casting process of single-crystal blades. Journal of Materials Processing Technology, 2011: 211; 2123-2131.

EDRAKI, M.; BaAUMGARTL, T.; MANLAPIG, E.; BRADSHAW, D.; FRANKS, D. M.; MORAN, C. J. Designing mine tailings for better environmental, social and economic outcomes: a review of alternative approaches. Journal of Cleaner Production, 2014: 84; 411-420.

NOVAES DE OLIVEIRA, A. P.; DAL BÓ FILHO, H.; CARVALHO, A. C.; DE OLIVEIRA MAIA, B. G.; CESCONETO, F. R.; RAUPP-PEREIRA, F. Desenvolvimento de isolantes térmicos a partir de fontes alternativas minerais. Cerâmica industrial, 2014: 19; 38-42.

DRAJEWICZ, M.; PYTEL, M. Recycling process of casting molds applying to precision castings. Journal of Achievements in Materials and Manufacturing Engineering. 2012; 55:(2) 661667.

International Organization for Standardization (ISO). ISO 13320: particle size analysis - Laser diffraction methods (E) content. Geneva, 2009.

ISMAEL, M. R.; VALENZUELA, F. A. O.; POLITO, L. A.; PANDOLFELLI, V. C. Propriedades termomecânicas de concretos refratários ligados por sílica coloidal. Cerâmica. 2007; 53: 314-318.

KAZEMI, A.; FAGHIHI-SANI, M.A.; ALIZADEH, H.R. Investigation on cristobalite crystallization in silica-based ceramic cores for investment casting. Journal of the European Ceramic Society. 2013; 33: 3397-3402.

LACERDA, S. S.; JOSÉ, A. A.; BORDIN, S. E. 2011. Valorização da casca cerâmica residual do processo de microfusão por incorporação em formulação de refratários. Abifa, 137:88-95.

LEE JH. Ternary phase analysis of interfacial silicates grown in $\mathrm{HfOx} / \mathrm{Si}$ and $\mathrm{Hf} / \mathrm{SiO} / \mathrm{Si}$ systems. Thin Solid Films. 2005; 472: 317-22.

LEONARDO, I. M. Avaliação microestrutural e propriedades de cascas cerâmicas contendo diferentes tamanhos e concentrações de nanopartículas de sílica coloidal. 2013. 247 p. Tese (Doutorado em Engenharia Metalúrgica, Materiais e de Minas). Universidade Federal de Minas Gerais, Belo Horizonte, MG. 2013. 
LIAO, D.; FAN, Z.; JIANG, W.; SHEN, E.; LIU, D. Study on the surface roughness of ceramic shells and castings in the ceramic shell casting process based on expandable pattern. Journal of Materials Processing Technology. 2011; 211: 1465-1470.

MACHADO, I. M. L. 2001. Tecnologia básica do processo de fundição por cera perdida. Senai, Belo Horizonte, Brasil.

MACHADO, I. Avaliação microestrutural de cascas cerâmicas utilizadas na produção de moldes para o processo de fundição por cera perdida. 2005. 119 p. Dissertation (Masters in Metalurgical and Mining Engineering). Universidade Federal de Minas Gerais, Belo Horizonte, 2005.

MACHADO, C. Reutilização da casca cerâmica do processo de fundição por cera perdida, como adição em matrizes cimentícias. 2013. 91 p. Dissertation (Masters in Materials Engineering). Centro federal de educação tecnológica de Minas Gerais - CEFET-MG, Belo Horizonte, 2013.

MALENSEK, N.; DUCMAN, V.; MIRTIC, B. Recycled granulate obtained from waste alumina-rich refractory powder by the cold bonding process. Ceramics International. 2015: 41; 8996-9002.

MICROMERITICS. Surface Area and Pore Structure by Gas Adsorption, chapter 3, 2016.

PATTNAIK, S.; KURANAKAR, D. B.; JHA, P. K. Developments in investment casting process - A review. Journal of Materials Processing Technology. 2012: 212; 2332-2348.

PATTNAIK, S. An investigation on enhancing ceramic shell properties using naturally available additives. Int J Manuf Technol. 2017: 91; 30613078.

PRASAD, R. Progress in Investment Castings. Available at: <http://cdn.intechopen.com/pdfs/ 39309/In Tech-Progress_in_investment_castings .pdf> Acess: July. 2021.

PETERS, T. M.; TWAROG, D. L. The feasibility of reclaiming investment shell material from investment casting. Hazardous Waste Research and Information Center One East Hazelwood Drive. Champaign, Illinois 61820, HWRIC Project RRT-10, 1992.

RAFIQUE, M. M. A.; IGBAL, J. Modeling and simulation of heat transfer phenomena during investment casting. International Journal of Heat and Mass Transfer. 2009: 52; 2132-2139.

REDDY, A. C. Thermo-physical properties of fused silica investment shell moulds at preheat conditions of steel casting. National Conference on Advanced Materials and Manufacturing Techniques. March 08-09, 2004.

SABEDOT, S.; WOTRUBA, H.; SAMPAIO, C. H.; PETTER, C. O.; de BRUM, I. A. S. Mineral processing of low quality zircon concentrates and preconcentrates. Mineral Processing and Extractive Metallurgy. 2009: 118; 114-121.

SCHNEIDER, H. Thermal expansion of mullite. J. Am. Ceram. Soc. 1990: 73; 2073-2076.

SOUZA, L. P. de F.; MANSUR, H. S. Production and characterization of ceramic pieces obtained by slip casting using powder wastes. Journal of Materials Processing Technology. 2004: 145; 1420.

VALENZA, F.; BOTTER, R.; CIRILLO, P.; BARBERIS, F.; DI FOGGIA, M.; SOTTILE, D. Sintering of waste of superalloy casting investment shells as a fine aggregate for refractory tiles. Ceramics international. 2010: 36; 459-463.

WILSON, P. J.; BLACKBURN, S.; GREENWOOD, R. W.; PRAJAPTI, B.; SMALLEY, K. The role of zircon particle size distribution, surface area and contamination on the properties of silica-zircon ceramic materials. Journal of the European Ceramic Society. 2011: 31; 1849-1855.

$\mathrm{XU}, \mathrm{M}$. Characterization of investment shell thermal properties. 2015. 119f. Doctorate Thesis in Metalurgical Engineering. Universidade Missouri, Ciência e Tecnologia, USA, 2015.

XU, M.; LEKAKH, S. N.; RICHARDS, V. L. Thermal property database for investment casting shells. International Journal of Metalcasting. 2016: 10; 329-337.

ZHAO, S.; HUANG, Y.; WANG, C.; HUANG, X.; GUO, J. Mullite formation from reaction sintering of $\mathrm{ZrSiO4/a-Al203}$ mixtures. Materials Letters. 2003: 57; 1716-1722.

\section{AUTHORS}

ORCID: 0000-0002-7164-6656

ALINI LUÍSA DIEHL CAMACHO (ALDC), Mestre Engenharia Civil. I Universidade do Vale do Rio dos Sinos (UNISINOS-RS) । PPG's em Engenharia Civil, Laboratório de Caracterização e Valorização de Materiais (LCVMat / UNISINOS) | São Leopoldo, RS, Brasil | Av. Unisinos, 950, Bairro Cristo Rei RS, 93022-750 | email: aldiehl@unisinos.br 
ORCID: 0000-0001-7088-2502

REGINA CÉLIA ESPINOSA MODOLO (RCEM), Dra. Ciências e Engenharia do Ambiente | Universidade do Vale do Rio dos Sinos (UNISINOS-RS) I PPG's em Engenharia Civil e Engenharia Mecânica | São Leopoldo, RS, Brasil | Av. Unisinos, 950, Bairro Cristo Rei - RS, 93022-750 | email: reginaem@unisinos.br

ORCID: 0000-0002-6295-1333

VICTOR MIGUEL FERREIRA (VMF), Dr. I Ciência e Engenharia de Materiais| Universidade de Aveiro (UA-PT) | Departamento de Engenharia Civil | Aveiro, Portugal, 3810-193 | email: victorf@ua.pt

ORCID: 0000-0002-3636-3933

FERNANDO JOAQUIM FERNANDES TAVARES ROCHA (FJFTR), |Professor Catedrático. | Universidade de Aveirol Curso de Geologia| Aveiro, Portugal | Correspondência para: Rua Manuel Vasconcelos, 26, 5 dto, 3810-498 Aveiro, Portugal | e-mail: tavares.rocha@ua.pt

ORCID: 0000-0001-7295-2826

CARLOS ALBERTO MENDES MORAES (CAMM), Dr. | Ciência dos Materiais | Universidade do Vale do Rio dos Sinos (UNISINOS-RS) | PPG's em Engenharia Civil e Engenharia Mecânica | São Leopoldo, RS, Brasil | Av. Unisinos, 950, Bairro Cristo Rei - RS, 93022-750 | email: cmoraes@unisinos.br

\section{HOW TO CITE THIS ARTICLE}

CAMACHO, Alini Luísa Diehl, MODOLO, Regina Célia Espinosa; FERREIRA, Victor Miguel, ROCHA, Fernando Joaquim Fernandes Tavares, MORAES, Carlos Alberto Mendes. Investigation of the Raw Materials from the Precision Casting Process for Viability Evaluation of Recycling the Generated Ceramic Shell Waste. MIX Sustentável, v. 8, n. 1, p. 53-66, jan. 2022. ISSN 24473073. Disponível em: <http://www.nexos.ufsc.br/index.php/mixsuste ntavel>. DOI: http://dx.doi.org/10.29183/24473073.MIX2022.v8.n1.53-65

Submitted: 30/04/2021

Approved: 20/08/2021

Published: 01/12/2021
Editor Responsável: Lisiane Ilha Librelotto

Registro da contribuição de autoria:

Taxonomia CRediT (http://credit.niso.org/)

ALDC, RCEM, VMF, FJFTR, CAMM: análise formal, visualização, escrita -rascunho original.

ALDC, RCEM, CAMM: validação, administração do projeto, supervisão,escrita -revisão e edição.

ALDC, CAMM: conceituação, curadoria de dados, investigação, metodologia.

Declaração de conflito: nada foi declarado. 